\title{
Growth of sugar cane varieties under salinity
}

\author{
Welson Lima Simões ${ }^{1 *}$, Marcelo Calgaro², Daniela Siqueira Coelho ${ }^{3}$, \\ Delfran Batista dos Santos ${ }^{4}$ Moisés Alves de Souza ${ }^{5}$
}

$10.1590 / 0034-737 X 201663020019$

\begin{abstract}
Large salty areas in the Brazilian semi-arid region have limited farming in Northeastern Brazil. One example is the sugar cane cultivation, which reinforces the need of selecting varieties that are more tolerant to salinity. The objective of this study was to evaluate the effect of salinity on growth of ten varieties of sugar cane. The experiment was conducted in a greenhouse, set in the experimental field of Embrapa Semiárido, in Petrolina, Pernambuco State. The experimental design was randomized blocks arranged in a $6 \mathrm{X} 10$ factorial arrangement, comprised of six levels of salinity $\left(0,1.0,2.0,4.0,6.0\right.$ and $\left.8.0 \mathrm{dS} \mathrm{m}^{-1}\right)$ and ten sugar cane varieties (VAT 90212; RB 72454; RB 867515; Q 124; RB 961003; RB 957508; SP791011; RB 835089; RB 92579 and SP 943206). Salt levels of irrigation water were obtained by adding NaCl, $\mathrm{CaCl}_{2} \cdot 2 \mathrm{H}_{2} \mathrm{O}$ and $\mathrm{MgSO}_{4} \cdot 7 \mathrm{H}_{2} \mathrm{O}$ to achieve an equivalent ratio among $\mathrm{Na}$ :Ca:Mg of 7:2:1. Sixty days later, plant height, stem diameter (base), number of leaves, stalks and sprouts, leaf area and fresh and dry mass of the aerial part and roots were all measured. The varieties of sugar cane showed similar responses for growth reduction as soil salinity increases, being considered moderately sensitive to salinity.
\end{abstract}

Key words: biomass, height, leaf area, salt stress.

\section{RESUMO}

\section{Crescimento de variedades de cana-de-açúcar submetidas à salinidade}

As extensas áreas salinizadas no semiárido têm limitado a produção agrícola no Nordeste brasileiro, a exemplo da cana-de-açúcar, o que reforça a necessidade de selecionar variedades mais tolerantes à salinidade. O objetivo do presente trabalho foi avaliar o efeito da salinidade no crescimento de dez variedades de cana-de-açúcar. O experimento foi realizado em vasos, em casa de vegetação, instalada no campo experimental da Embrapa Semiárido, em Petrolina-PE. O delineamento experimental utilizado foi em blocos casualizados dispostos em arranjo fatorial de 6 X 10, considerandose seis níveis de salinidade na água de irrigação $(0 ; 1,0 ; 2,0 ; 4,0 ; 6,0$ e 8,0 dS m-1) e dez variedades de cana-de-açúcar (VAT 90212, RB 72454, RB 867515, Q 124, RB 961003, RB 957508, SP 791011, RB 835089, RB 92579 e SP 943206). Os níveis de salinidade da água de irrigação foram obtidos pela adição de $\mathrm{NaCl}, \mathrm{CaCl}_{2} \cdot 2 \mathrm{H}_{2} \mathrm{O}$ e $\mathrm{MgSO}_{4} \cdot 7 \mathrm{H}_{2} \mathrm{O}$, de modo a se obter proporção equivalente entre $\mathrm{Na}: \mathrm{Ca}: \mathrm{Mg}$ de 7:2:1. Após sessenta dias foram feitas medidas de altura das plantas, diâmetro do colmo (base), número de folhas, colmos e brotações, área foliar e massas de matéria fresca e seca da parte aérea e raízes. As variedades de cana-de-açúcar apresentam respostas semelhantes quanto à redução do crescimento à medida que a salinidade do solo aumenta, sendo consideradas moderadamente sensíveis à salinidade.

Palavras-chave: estresse salino, altura, biomassa, área foliar.

\footnotetext{
Submitted on 02/20/2014 and approved on 01/20/2016.

'Empresa Brasileira de Pesquisa Agropecuária Semiárido, Petrolina, Pernambuco State, Brazil. welson.simoes@embrapa.br

2Empresa Brasileira de Pesquisa Agropecuária Semiárido, Petrolina, Pernambuco State, Brazil. marcelo.calgaro@embrapa.br

${ }^{3}$ Universidade Federal Rural de Pernambuco, Department of Soils, Recife, Pernambuco State, Brazil. daniela.coelho@hotmail.com.br

${ }^{4}$ Instituto Federal Baiano, Department of Irrigation, Senhor do Bonfim, Bahia State, Brazil. delfran.batista@gmail.com

${ }^{5}$ Universidade do Estado da Bahia, Department of Technology , Juazeiro, Bahia State, Brazil. moisesalves-1989@ hotmail.com

*Corresponding author: welson.simoes@embrapa.br
} 


\section{INTRODUCTION}

Sugar cane production in northeastern Brazil was estimated at 61.2 million tonnes, representing $9.34 \%$ of the Brazilian average (CONAB, 2015). Most of that is produced in northeastern semi-arid region, more specifically in the Submiddle of São Francisco River Valley that has achieved high yields of that crop due to irrigation technologies used (Silva, 2009).

However, because of soil and climate conditions favorable to soil salinization, the semiarid region presents some limitations on the exploitation of certain areas for the production of sugar cane due to the negative effect of salts on the growth and development of this crop.

As a result, the need of selecting genetic material with greater production potential under salt conditions (García \& Medina, 2003) is important to facilitate the use of these areas and to achieve greater economic returns.

Wahid \& Ghazanfar (2006) state that the existing varieties present some differences among them regarded to salt tolerance. Santana et al. (2007) state that sugar cane yield can be reduced by $50 \%$ in soils with electrical

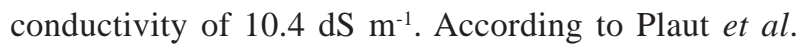
(2000), using salt water over $8 \mathrm{dS} \mathrm{m}^{-1}$ promotes severe effects on the growth of sugar cane varieties, with a significant reduction in leaf area and perspiration, and the increase in senescence and greater accumulation of $\mathrm{Na}^{+}$and $\mathrm{Cl}^{-}$.

The different responses obtained from varieties of sugar cane regarding tolerance to salinity are related to the mechanisms developed by them to minimize the osmotic effect of salts in the soil, which limits the water absorption besides the less vulnerability to toxic concentrations of ions such as $\mathrm{Na}^{+}$and $\mathrm{Cl}^{-}$(Munns \& Tester, 2008).

The salt effects on the sugar cane are displayed with some restrictions in the assimilation of $\mathrm{CO}_{2}$ (Vasantha et al., 2010), decrease in chlorophyll content (Silva et al., 2010), reduction in turgor pressure, limited elongation and cell division (Taiz \& Zeiger, 2013), accumulation of compounds known as reactive oxygen species (Willadino et al., 2011) among other factors that directly reflect the depletion of plant growth.

Thus, morphological variables can help to evaluate the degree of salt tolerance of plants, as they express their adaptive traits to survive under stressful conditions. The objective of this study was to evaluate the effect of salinity on growth of ten sugar cane varieties.

\section{MATERIAL AND METHODS}

The experiment was conducted in a greenhouse set at EMBRAPA - Semi-Arid in the city of Petrolina, State of Pernambuco (latitude: 909'S, longitude: $40^{\circ} 22^{`} \mathrm{~W}, 365.5 \mathrm{~m}$ above sea level). The climate in the region is the BSWh type according to Köppen, semi-arid tropical as described by Reddy \& Amorim Neto (1983).

This experiment used a random block design in a 6 X 10 factorial arrangement, where six salt levels were represented by electrical conductivity (EC) of the irrigation water: 0 , 1.0, 2.0, 4.0, 6.0 and $8.0 \mathrm{dS} \mathrm{m}^{-1}$, and ten sugar cane varieties: VAT 90212(V1), RB 72454(V2), RB 867515(V3), Q 124(V4), RB 961003(V5), RB 957508(V6), SP791011(V7), RB 835089 (V8), RB 92579 (V9) and SP 943206 (V10); totaling sixty treatments and three replicates.

To conduct the experiment, $8-\mathrm{dm}^{3}$ polyethylene pots were used, filled with a Quartzipsamment whose chemical and textural characteristics are shown in Table 1. The soil was air-dried, crushed, sieved in a 5-mm mesh sieve and homogenized.

According to the results of soil analysis, its fertility was corrected by applying dolomitic limestone $(620 \mathrm{mg}$ $\mathrm{dm}^{-3}$ ) 45 days prior to planting and subsequent nutrient supply considering the following values: $118 \mathrm{mg} \mathrm{dm}^{-3} \mathrm{P}$ (single application), 70 and $100 \mathrm{mg} \mathrm{dm}^{-3}$ of $\mathrm{N}$ and $\mathrm{K}$, respectively, applied in two splits: 14.8, 3.7, 4.0, 34.8 and $7.6 \mathrm{mg} \mathrm{dm}^{-3} \mathrm{Cu}, \mathrm{B}, \mathrm{Mn}, \mathrm{Zn}$ and Fe, respectively, split in three applications.

In each pot, two sugar cane sprouts were planted. Those sprouts were from the Active Germplasm Bank of Embrapa and Agroindústria do Vale do São Francisco (Agrovale). Then, the soil was moistened up to field capacity, using salt-free water.

The salt water used in irrigation were prepared from the salts $\mathrm{NaCl}, \mathrm{CaCl}_{2} \cdot 2 \mathrm{H}_{2} \mathrm{O}$ and $\mathrm{MgSO}_{4} \cdot 7 \mathrm{H}_{2} \mathrm{O}$, in order to obtain equivalent ratio of 7:2:1 between $\mathrm{Na}: \mathrm{Ca}: \mathrm{Mg}$ (Aquino et al., 2007). The water was renewed weekly and stored in a fresh, shady place in order to avoid alterations of the EC values for possible evaporation and temperature variations. The salt water was applied every two days in order to raise soil moisture to field capacity, with $15 \%$ leaching fraction.

After sixty days of salt stress, the following measurements were taken: plant height, stem diameter (base), number of leaves, stalks and sprouts and then removal of plants was started. The total leaf area was determined by means of $\mathrm{Li}-3100 \mathrm{C}$ countertop scanner. The plants were separated into aerial part and roots, weighed to determine their respective values of fresh matter. After that, they were placed in oven at $65^{\circ} \mathrm{C}$ for 72 hours and weighed again, and mass of dry matter of the aerial part and roots were set.

The data were submitted to analysis of variance using the Sisvar 5.0 programme. For situations where there was a significant interaction between varieties and salinity levels, variable unfolding was carried out within each factor, otherwise, the independent effect of the factors was considered for the variables studied. 
For comparison among salt levels, regression models of first and second degrees were evaluated when they were significant up to $5 \%$ probability. For comparison between the varieties, the Scott Knott test was performed at $5 \%$ probability.

\section{RESULTS AND DISCUSSION}

From the analysis of variance, it was found that the interaction between varieties and electrical conductivity $\left(\mathrm{EC}_{\mathrm{w}}\right)$ was not significant for the studied variables (Table 2). However, significant differences between varieties were found, regardless of the salt level for plant height $(\mathrm{PH})$, number of stalks (NST), leaves (NL) and sprouts (NSP), leaf area (LA), fresh and dry mass of the aerial part (FMAP and DMAP) and root fresh mass (RFM)

When the $\mathrm{EC}_{\mathrm{w}}$ variation factor was evaluated, it was found that the attributes plant height, number of stalks, leaf area, fresh mass or the aerial part, dry mass of the aerial part, root dry mass and diameter showed significant responses for the different levels of salinity, regardless the analyzed variety (Table 2).

With regard to the variable height of the plants, it was found that the variety RB 835089 showed the best performance $(117.2 \mathrm{~cm}$ ) followed by varieties RB 72454, RB
957508, SP943206, RB 92579 and SP 791011, which showed average heights of 91.0, 81.1, 80.0, 78.7 and $77.9 \mathrm{~cm}$, respectively. Varieties with greater height may present greater production potential as a positive correlation between growth of stalks and productivity has already been observed (Silva, 2009).

As for the variable number of stalks, it was found that the variety RB 835089 showed the highest value (8.4) followed by the varieties RB 957508, SP 943206, RB72454, RB 867515 and SP 791011, which presented values of 6.6, 6.2, 5.8, 5.8 and 5.8 respectively (Table 3 ).

It was also found that the variety RB835089 showed the highest value for number of leaves followed by varieties Q124 and RB 961003. The varieties 867515, Q 124, RB 961003, SP 791011, RB 92579 and SP 943206 showed similar behavior for number of sprouts (Table 3). Although Silva (2007) stated that plants with higher number of sprouts tend to have lower values of stem diameter, no significant differences were found between the varieties studied for this variable. In addition, its average value was $1.9 \mathrm{~cm}$.

The variable number of leaves was partly correlated with the leaf area - LA (Table 4) since it showed higher values for RB 835089 and RB961003, although the variety VAT 90212 stood out, as well.

Table 1: Chemical and physical characteristics of the soil used for growing sugar cane varieties under different salt levels

\begin{tabular}{|c|c|c|c|c|c|c|c|c|}
\hline O.M. & $\mathrm{pH} \mathrm{H_{2 }} \mathrm{O}$ & $\mathbf{E C}_{\mathrm{se}}$ & $\mathrm{Ca}^{+2}$ & $\mathbf{M g}^{+2}$ & $\mathrm{Na}^{+}$ & $\mathbf{K}^{+}$ & $\mathbf{A l}^{+3}$ & $\mathbf{T}$ \\
\hline $\mathrm{g} \mathrm{kg}^{-1}$ & $(1: 2,5)$ & $d S m^{-1}$ & \multicolumn{6}{|c|}{$\mathrm{cmol}_{\mathrm{c}} \mathrm{dm}^{-3}$} \\
\hline 10.2 & 4.8 & 0.6 & 1.4 & 0.4 & 0.04 & 0.28 & 0.05 & 3.6 \\
\hline $\mathbf{P}$ & $\mathbf{V}$ & $\mathrm{Cu}$ & $\mathrm{Fe}$ & Mn & Zn & Sand & Silt & Clay \\
\hline $\mathrm{mg} \mathrm{dm^{-3 }}$ & $\%$ & \multicolumn{4}{|c|}{$\mathrm{mg} \mathrm{dm}^{-3}$} & & $\%$ & \\
\hline 4.2 & 59 & 0.2 & 9.1 & 12.0 & 1.1 & 73.0 & 19.0 & 8.0 \\
\hline
\end{tabular}

$\mathrm{EC}_{\mathrm{se}}=$ electrical conductivity of saturation extract; $\mathrm{OM}=$ organic matter; $\mathrm{P}=$ available phosphorus extracted by $\mathrm{Mehlich}^{-1} ; \mathrm{Ca}^{2+}=$ exchangeable $^{2}$ calcium; $\mathrm{Mg}^{2+}=$ exchangeable magnesium; $\mathrm{Na}^{+}=$exchangeable sodium; $\mathrm{K}^{+}=$exchangeable potassium; $\mathrm{Al}^{+3}$ : exchangeable acidity; $\mathrm{T}=$ cation Exchange capacity at $\mathrm{pH} 7.0 ; \mathrm{V}=$ base saturation; $\mathrm{Fe}=$ available iron; $\mathrm{Mn}=$ available manganese; $\mathrm{Cu}=$ available cupper; $\mathrm{Zn}=$ available zinc. Micronutrients extracted with Mehlich ${ }^{-1}$

Table 2: Analysis of variance for growth variables in varieties of sugar cane under different salt levels

\begin{tabular}{|c|c|c|c|c|c|}
\hline \multirow{2}{*}{ Factor of variation } & \multicolumn{5}{|c|}{ Mean Square } \\
\hline & PH & $\theta$ & NL & NST & NSP \\
\hline Varieties & $4.146^{* *}$ & $0.17^{\mathrm{ns}}$ & $7.92^{* *}$ & $26.1^{* *}$ & $15.5^{* *}$ \\
\hline $\mathrm{EC}_{\mathrm{w}}$ & $7.106^{* *}$ & $0.24^{*}$ & $1.35^{\mathrm{ns}}$ & $24.5^{* *}$ & $0.80^{\mathrm{ns}}$ \\
\hline Varieties X EC ${ }_{w}$ & $240.8^{\text {ns }}$ & $0.08^{\mathrm{ns}}$ & $1.09^{\mathrm{ns}}$ & $1.35^{\mathrm{ns}}$ & $2.02^{\mathrm{ns}}$ \\
\hline \multirow[t]{2}{*}{ Residue } & 246.7 & 0.10 & 0.9 & 1.46 & 1.86 \\
\hline & LA & FMAP & DMAP & RFM & RDM \\
\hline Varieties & $339.313^{* *}$ & $45.630^{* *}$ & $3.017^{* *}$ & $75.635^{* *}$ & $4.035^{\mathrm{ns}}$ \\
\hline $\mathrm{EC}_{\mathrm{w}}$ & $539.086^{* *}$ & $75.043^{* *}$ & $2.828^{* *}$ & $151.018^{* *}$ & $29.414^{* *}$ \\
\hline Varieties X EC & $96.498^{\mathrm{ns}}$ & $4.078^{\mathrm{ns}}$ & $634.3^{\mathrm{ns}}$ & $17.233^{\mathrm{ns}}$ & $3.192^{\mathrm{ns}}$ \\
\hline Residue & 70.613 & 4.148 & 779.5 & 12.759 & 3.313 \\
\hline
\end{tabular}

PH - plant height; $\theta$ - stalk diameter; NF- Number of leaves; NST-number of stalks; NSP- Number of sprouts; LA- leaf area; FMAP- fresh mass of the aerial part; DMAP- dry matter of the aerial part; RFM- root fresh mass; RDM- root dry mass; *** and ns are significant at $5 \%$, $1 \%$ and non-significant, respectively. 
Plants with larger leaf area (LA) may have greater production potential due to their higher capacity of intercepting solar radiation and biomass accumulation (Sinclair et al., 2004). This fact was observed in RB 835089 , which presented higher production of fresh (FMAP) and dry (DMAP) mass of the aerial part, however, it was not observed an increase in the translocation of photoassimilates to the roots, to contribute to their root development (Table 4).

For root dry matter mass, no significant differences between the varieties (Table 4) were found, which may be due to the high value of the coefficient of variation (64.4\%), showing that this is not a suitable variable for evaluating the potential of varieties regarded to their salt tolerance since their variances are influenced by other factors besides salt stress.

When the influence of the levels of salt stress on the plants of sugar cane was evaluated, it was found that regardless of the studied variety, plant height, stem diameter and number of stems reduced significantly as values of $\mathrm{EC}_{\mathrm{w}}$ increased (Figure 1).
For the conditions of this study, reductions of 37.2 and $30.8 \%$ were observed in plant height and number of stalks, respectively, when comparing the results obtained with plants exposed to the highest salt level with those irrigated with not-saline water. However, the variable stem diameter was less sensitive to the effects of salinity, when presenting reduction of only $8 \%$ for these same conditions.

When working with sugar cane, Santana et al. (2007) obtained similar results, showing that salinity affected crop growth in na inversely proportional manner to the salt concentration in the irrigation water. Other authors (Gurgel et al., 2003; Willadino et al., 2011; Almeida et al., 2012), working with genotypes and varieties of different crops also report the deleterious effects of the salts on the physiological variables and growth.

Salt levels did not affect the number of sprouts, demonstrating that this is a variable more related to genetic differences among varieties than a particular response to the environmental conditions.

García \& Medina (2010) when evaluating two genotypes of sugar cane under salt conditions found that

Table 3: Plant height (PH), stalk diameter ( $\theta$ ), number of leaves (NF), number of stalks (NST) and number of sprouts (NSP) for different varieties of sugar cane

\begin{tabular}{lccccc}
\hline Varieties & PH $(\mathbf{c m})$ & $\boldsymbol{\theta}(\mathbf{c m})$ & $\mathbf{N L}$ & $\mathbf{N S T}$ & NSP \\
\hline VAT 90212 & $74.1 \mathrm{c}$ & $1.9 \mathrm{a}$ & $6.2 \mathrm{c}$ & $5.1 \mathrm{c}$ & $1.1 \mathrm{~b}$ \\
RB 72454 & $91.0 \mathrm{~b}$ & $1.9 \mathrm{a}$ & $6.2 \mathrm{c}$ & $5.8 \mathrm{~b}$ & $0.9 \mathrm{~b}$ \\
RB 867515 & $70.3 \mathrm{c}$ & $2.0 \mathrm{a}$ & $5.4 \mathrm{c}$ & $5.8 \mathrm{~b}$ & $2.9 \mathrm{a}$ \\
Q 124 & $67.8 \mathrm{c}$ & $1.7 \mathrm{a}$ & $6.8 \mathrm{~b}$ & $5.1 \mathrm{c}$ & $2.7 \mathrm{a}$ \\
RB 961003 & $62.6 \mathrm{c}$ & $2.0 \mathrm{a}$ & $6.4 \mathrm{~b}$ & $3.8 \mathrm{~d}$ & $2.5 \mathrm{a}$ \\
RB 957508 & $81.1 \mathrm{~b}$ & $1.8 \mathrm{a}$ & $5.6 \mathrm{c}$ & $6.6 \mathrm{~b}$ & $1.3 \mathrm{~b}$ \\
SP 791011 & $77.9 \mathrm{~b}$ & $1.9 \mathrm{a}$ & $5.7 \mathrm{c}$ & $5.8 \mathrm{~b}$ & $3.4 \mathrm{a}$ \\
RB 835089 & $117.2 \mathrm{a}$ & $1.8 \mathrm{a}$ & $7.5 \mathrm{a}$ & $8.4 \mathrm{a}$ & $1.1 \mathrm{~b}$ \\
RB 92579 & $78.7 \mathrm{~b}$ & $1.9 \mathrm{a}$ & $5.4 \mathrm{c}$ & $4.9 \mathrm{c}$ & $3.0 \mathrm{a}$ \\
SP 943206 & $80.0 \mathrm{~b}$ & $2.1 \mathrm{a}$ & $5.8 \mathrm{c}$ & $6.2 \mathrm{~b}$ & $2.3 \mathrm{a}$ \\
\hline C.V. $(\%)$ & 19.6 & 16.3 & 15.5 & 21.0 & 64.7 \\
\hline
\end{tabular}

* Means followed by the same letter in the column do not differ from each other by the test of Scott Knott at $5 \%$ of probability.

Table 4: Leaf area (LA), fresh mass of the aerial part (FMAP) and roots (RFM) and dry mass of the aerial part (DMAP) and roots (RDM) for different varieties of sugar cane

\begin{tabular}{|c|c|c|c|c|c|}
\hline Varieties & $\mathbf{L A}\left(\mathbf{c m}^{2}\right)$ & FMAP (g) & DMAP (g) & RFM (g) & RDM (g) \\
\hline VAT 90212 & $1165.8 \mathrm{a}$ & $209.4 \mathrm{~b}$ & $52.3 \mathrm{~b}$ & $383.6 \mathrm{~b}$ & $83.3 \mathrm{a}$ \\
\hline RB 72454 & $951.0 \mathrm{~b}$ & $229.8 \mathrm{~b}$ & $61.1 \mathrm{~b}$ & $396.5 \mathrm{~b}$ & $53.7 \mathrm{a}$ \\
\hline RB 867515 & $814.6 \mathrm{~b}$ & $172.6 \mathrm{c}$ & $63.7 \mathrm{~b}$ & $303.0 \mathrm{c}$ & $36.9 \mathrm{a}$ \\
\hline Q 124 & $857.9 \mathrm{~b}$ & $152.1 \mathrm{c}$ & $44.9 \mathrm{~b}$ & $465.2 \mathrm{a}$ & $64.5 \mathrm{a}$ \\
\hline RB 961003 & $1159.9 \mathrm{a}$ & $192.0 \mathrm{~b}$ & $53.9 \mathrm{~b}$ & $416.6 \mathrm{~b}$ & $78.4 \mathrm{a}$ \\
\hline RB 957508 & 909.9 b & $199.6 \mathrm{~b}$ & $50.9 \mathrm{~b}$ & $443.2 \mathrm{~b}$ & $52.4 \mathrm{a}$ \\
\hline SP 791011 & $924.1 \mathrm{~b}$ & $215.4 \mathrm{~b}$ & $66.1 \mathrm{~b}$ & $421.5 \mathrm{~b}$ & $69.9 \mathrm{a}$ \\
\hline RB 835089 & $1166.5 \mathrm{a}$ & $340.1 \mathrm{a}$ & $91.5 \mathrm{a}$ & $373.5 \mathrm{~b}$ & $61.0 \mathrm{a}$ \\
\hline RB 92579 & 877.7 b & $201.2 \mathrm{~b}$ & $54.5 \mathrm{~b}$ & $343.6 \mathrm{c}$ & $42.4 \mathrm{a}$ \\
\hline SP 943206 & 896.7 b & $195.3 \mathrm{~b}$ & $54.2 \mathrm{~b}$ & $539.2 \mathrm{a}$ & $72.2 \mathrm{a}$ \\
\hline C.V. $(\%)$ & 27.3 & 30.6 & 47.1 & 27.8 & 64.4 \\
\hline
\end{tabular}

* Means followed by the same letter no differ from each other by the test of Scott Knott at $5 \%$ of probability.

Rev. Ceres, Viçosa, v. 63, n.2, p. 265-271, mar/abr, 2016 
genotype PR 692176 showed higher value for the number of sprouts when compared with the genotype V78-1, thus strengthening the hypothesis that genotypes or varieties may have different responses for the same level of salt.

The effect of the soil salt levels on variables leaf number and leaf area are shown in Figure 2. It is observed that the number of leaves remained almost constant with increasing salt levels, while the leaf area (LA) was negatively affected, demonstrating greater influence of salts on the leaf expansion, therefore contributing to alterations in values of leaf area (LA). In this case, leaf área increased up to level of salinity corresponding to $5.2 \mathrm{dS} \mathrm{m}^{-1}$, when its maximum value $\left(1.139 \mathrm{~cm}^{2}\right)$ is achieved; from that point, it declines up to the value of $1.045 \mathrm{~cm}^{2}$, corresponding to salinity of $8 \mathrm{dS} \mathrm{m}^{-1}$.
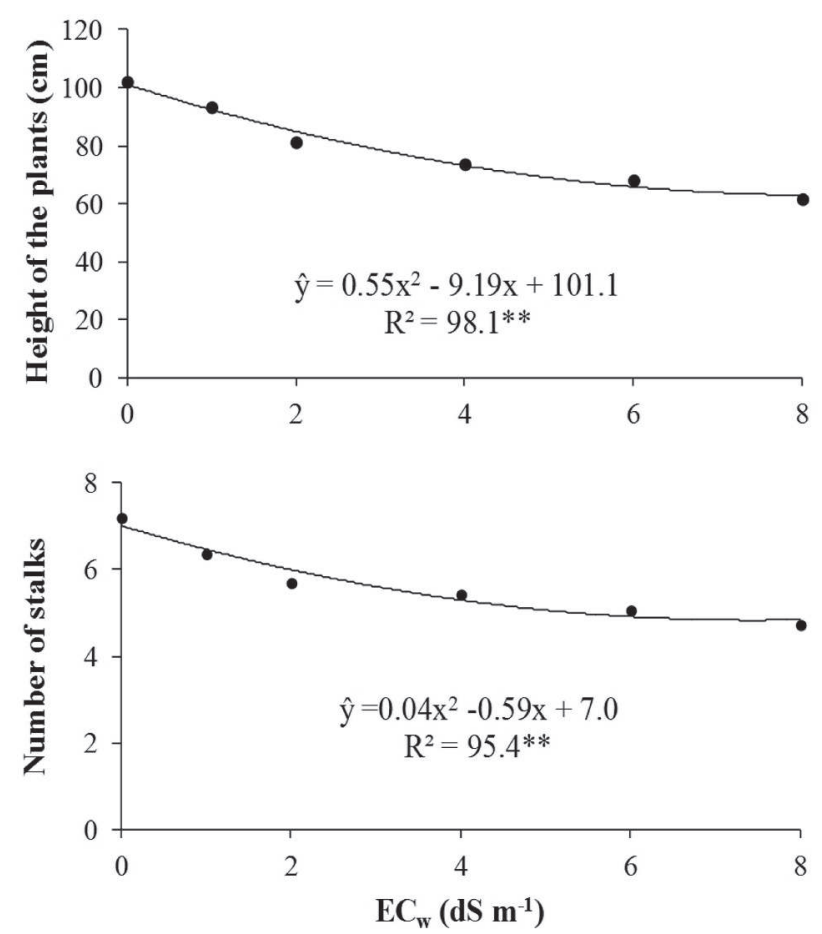

This characteristic may be related to osmotic adjustment mechanisms developed by plants, in which the effect of the absorption and transport of ions to the aerial part and accumulation of compatible solutes promotes the maintenance of the leaf water status up to certain salt levels not considered toxic to plants (Munns \& Tester, 2008).

The sensitivity of leaf area in relation to salt effects on varieties of sugar cane grown in growth chambers in North Carolina (USA) were also reported by García \& Medina (2010).

The variables fresh mass of the aerial part, dry mass of the aerial part, root fresh mass and root dry mass were significantly influenced by the salt levels in the soil, regardless of the studied range (Figure 3). For these variables, there were linear reductions with soil salinity
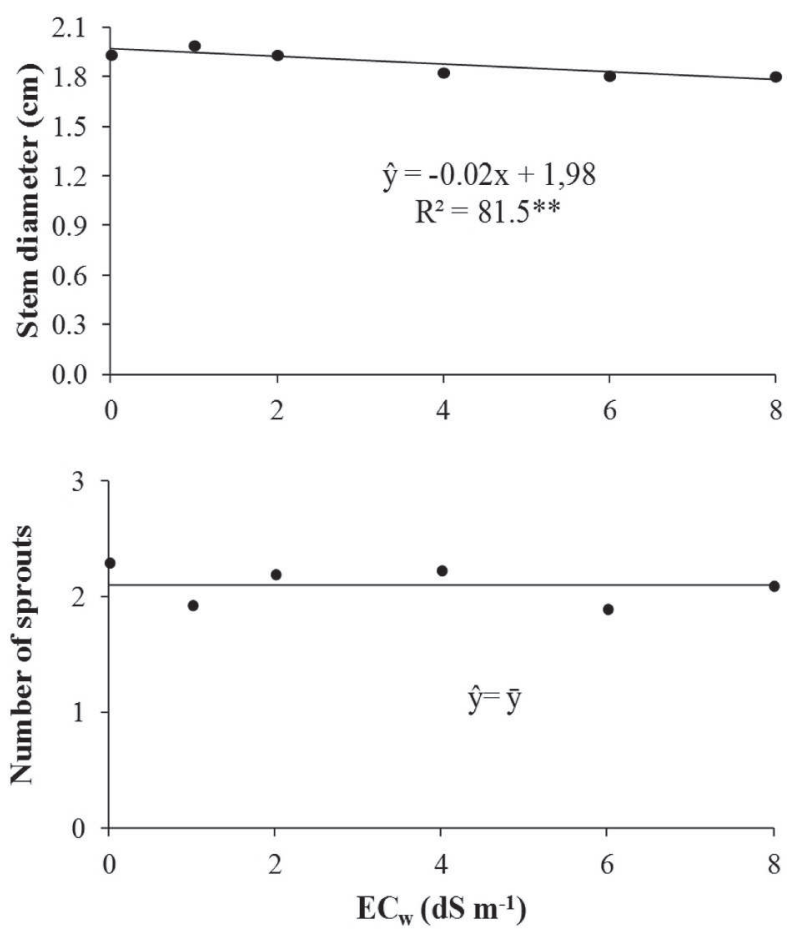

Figure 1: Height of the plants, stem diameter, number of stalks and number of sprouts in sugar cane plants under different levels of salinity. ** Significant regressions at $1 \%$ of probability.
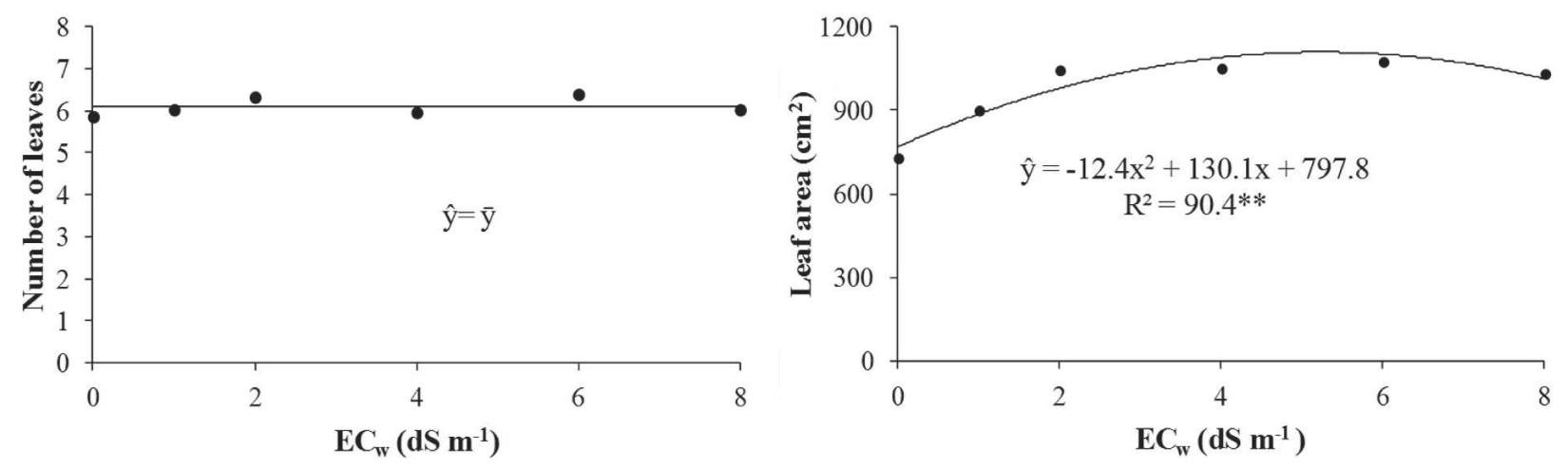

Figure 2: Number of leaves, leaf area in sugar cane plants under different levels of salt. ** Significant regression at $1 \%$ of probability. 

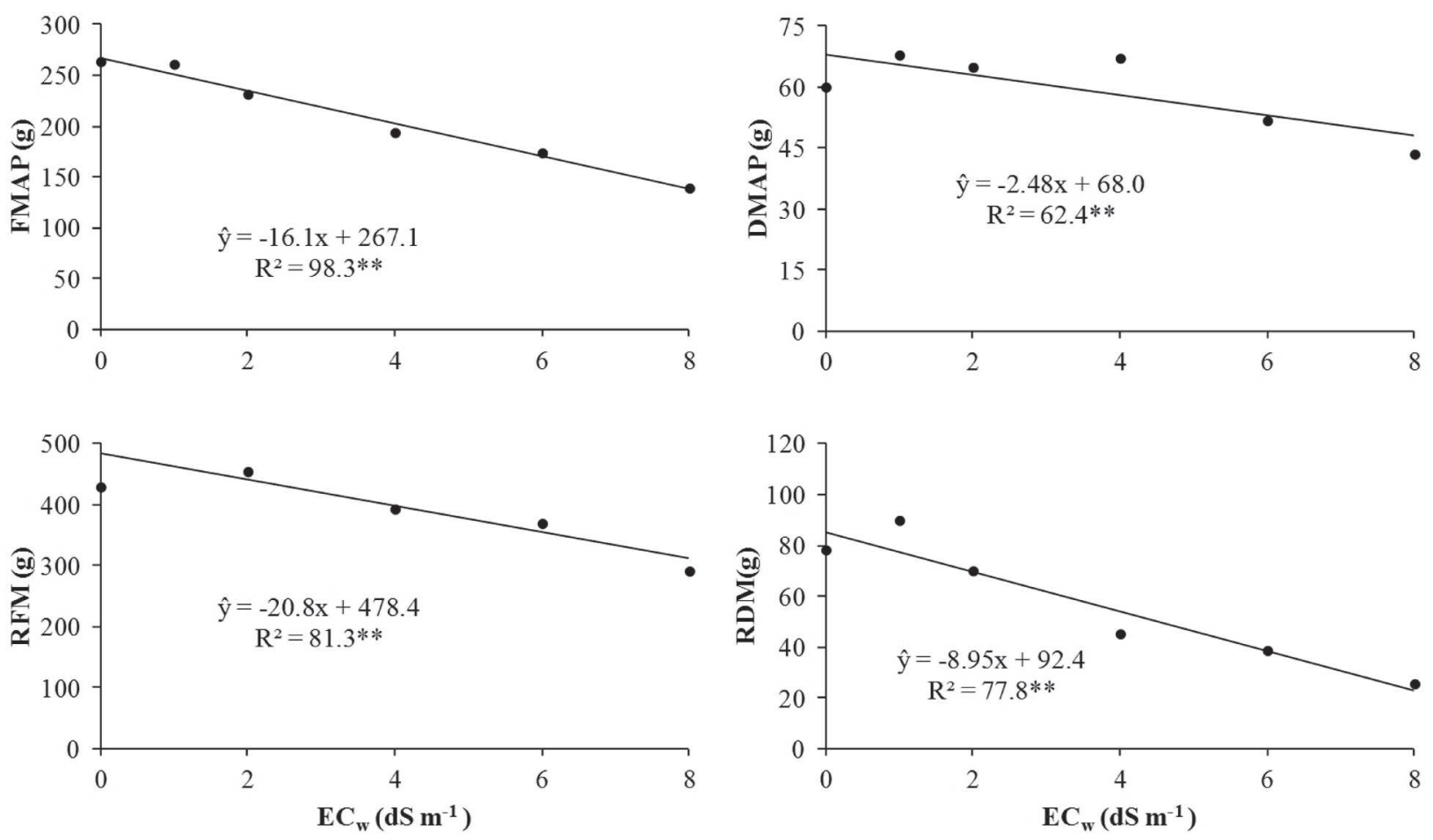

Figure 3: Fresh mass of the aerial part (FMAP) and roots (RFM) and dry mass of the aerial part (DMAP) and roots (RDM) in sugar cane plants under different levels of salt. ** significant regression at $1 \%$ of probability.

levels, reaching relative reductions of $48,29,35$ and $77 \%$, respectively, for the treatment at $8 \mathrm{dS} \mathrm{m}^{-1}$ when compared to the control $\left(0.1 \mathrm{dS} \mathrm{m}^{-1}\right)$, showing higher sensitivity of root dry mass to the variation of soil salinity and lower sensitivity for the dry mass of the aerial part.

It was found that for every increase of $1 \mathrm{dS} \mathrm{m}^{-1}$ in the irrigation water, fresh mass of the aerial part, dry mass of the aerial part, root fresh mass and root dry mass decreased by $6.0,3.6,4.4$ and $9.6 \%$ respectively. Of these results, dry mass of the aerial part is the variable that is the closest to the values pointed by Fageria et al. (2010), who suggest a reduction of $5.9 \%$ in the yield of this crop for each $\mathrm{EC}_{\mathrm{se}}$ unit. Thus, based on the criterion used by Maas (1986), the evaluated sugar cane varieties can be considered moderately sensitive to salinity.

Santana et al. (2007), working with sugar cane (SP801842) under salt stress in greenhouse using soils with different textures (sandy, clayey and medium texture) and irrigation water salinity ranging from 0.1 to $8 \mathrm{dS} \mathrm{m} \mathrm{m}^{-1}$, also observed that dry mass of the aerial part and the root dry mass were significantly affected by the salt effect on different types of soil.

\section{CONCLUSIONS}

The evaluated sugar cane varieties have similar responses in reducing the growth as the salinity increases, being considered moderately sensitive to salinity.

\section{REFERENCES}

Almeida WS, Fernandes FRB, Bertini CHCM, Pinheiro MS \& Teofilo EM (2012) Estresse salino em genótipos de feijãocaupi durante a germinação e estabelecimento das plântulas. Revista Brasileira de Engenharia Agrícola e Ambiental, 16:10471054.

Aquino AJS, Lacerda CF \& Gomes-Filho E (2007) Crescimento, partição de matéria seca e retenção de $\mathrm{Na}^{+}, \mathrm{K}^{+}$e $\mathrm{Cl}^{-}$em dois genótipos de sorgo irrigados com águas salinas. Revista Brasileira de Ciência do Solo, 31:961-971.

CONAB - Companhia Nacional de Abastecimento (2015) Acompanhamento da safra brasileira: Cana-de-Açúcar. v.2 - safra 2015/ 2016 - n.2, segundo levantamento. Brasília, Embrapa. p.1-30.

Fageria NK, Soares Filho W \& Gheyi HR (2010) Melhoramento genético vegetal e seleção de cultivares tolerantes à salinidade. In: Ghey HR, Dias NS \& Lacerda CF (Eds.) Manejo da salinidade na agricultura: Estudos básicos e aplicados. Fortaleza, Instituto Nacional de Ciência e Tecnologia em Salinidade. p.130-141.

García M \& Medina E (2003) Crescimiento y acumulación de prolina en dos genotipos de caña de azúcar sometidos a salinización con cloruro de sodio. Revista de la Facultad de Agronomía, 20:168-179.

García M \& Medina E (2010) Crecimiento y morfología radical en dos genotipos de caña de azúcar (Saccharum spp.) sometidos a salinización con sales simples o suplementadas con cálcio. Revista de la Facultad de Agronomía, 27:17-38.

Gurgel MT, Fernandes PD, Gheyi HR, Santos FJS, Bezerra IL \& Nobre RG (2003) Estresse salino na germinação e formação de porta-enxerto de aceroleira. Revista Brasileira de Engenharia Agrícola e Ambiental, 7:31-36.

Maas EV (1986) Salt tolerance in plants. Applied Agricultural Research, 1:12-26. 
Munns R \& Tester M (2008) Mechanisms of salinity tolerance. Annual Review of Plant Biology, 59:651-681.

Plaut Z, Meinzer FC \& Federman E (2000) Leaf development, transpiration and ion uptake and distribution in sugar cane cultivars grown under salinity. Plant Soil, 218:59-69.

Reddy SJ \& Amorim Neto MS (1983) Dados de precipitação, evapotranspiração potencial, radiação solar global de alguns locais e classificação climática do Nordeste do Brasil. Petrolina, Embrapa. 280p.

Santana MJ, Carvalho JA, Souza AMG, Sousa KJ, Vasconcelos CL \& Andrade LAB (2007) Efeitos da salinidade da água de irrigação na brotação e desenvolvimento inicial da cana-de-açúcar (Saccharum spp) e em solos com diferentes níveis texturais. Ciência e Agrotecnologia, 31:1470-1476.

Silva EN, Ribeiro RV, Ferreira-Silva SL, Viégas RA \& Silveira JAG (2010) Comparative effects of salinity and water stress on photosynthesis, water relations and growth of Jatropha curcas plants. Journal of Arid Environments, 74:1130-1137.

Silva LC (2007) Análise de crescimento e acúmulo nutrientes de sete cultivares de cana-de-açúcar na Região de coruripe. Dissertação de Mestrado, Universidade Federal de Alagoas, Maceió. $127 \mathrm{p}$.
Silva TGF (2009) Análise de crescimento, interação biosfera-atmosfera e eficiência do uso de água da cana-de-açúcar irrigada no Submédio do Vale do São Francisco. Tese de Doutorado. Universidade Federal de Viçosa, Viçosa. 176p.

Sinclair TR, Gilbert RA, Perdomo RE, Shine Jr JM, Powell G \& Montes G (2004) Sugar cane leaf area development under field conditions in Florida, USA. Field Crops Research, 88:171-178.

Taiz L \& Zeiger E (2013) Fisiologia Vegetal. 5 ${ }^{\text {a }}$ ed. Porto Alegre, ArtMed. 954p.

Vasantha S, Venkataramana S, Rao PNG \& Gomathi R (2010) Long term salinity effect on growth, photosynthesis and osmotic characteristics in sugar cane. Sugar Tech, 12:5-8.

Wahid A \& Ghazanfar A (2006) Possible involvement of some secondary metabolites in salt tolerance of sugar cane. Journal of Plant Physiology, 163:723-730.

Willadino L, Oliveira Filho RA, Silva EA, Gouveia Neto AS \& Camara TR (2011) Estresse salino em duas variedades de canade-açúcar: enzimas do sistema antioxidativo e fluorescência da clorofila. Revista Ciência Agronômica, 42:417-422. 